\title{
BCR/ABL1 Fusion Protein with ABL1 NP_005148.2:p.F317L
}

National Cancer Institute

\section{Source}

National Cancer Institute. BCR/ABL1 Fusion Protein with ABL1 NP 005148.2:p.F317L. NCI

Thesaurus. Code C130219.

A fusion protein encoded by the BCR/ABL1 fusion gene with ABL1

NM_005157.4:C.951C>A, c.951C>G or c.949T >C mutation. This protein is comprised of

the $\mathrm{N}$-terminus of the breakpoint cluster region protein fused to almost the entire tyrosine-protein kinase ABL1 protein where the phenylalanine at position 317 of the ABL1 protein has been replaced by leucine. 